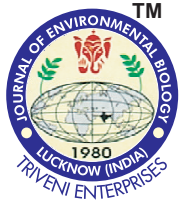

DOI : http://doi.org/10.22438/jeb/39/5(SI)/18
Journal of Environmental Biology

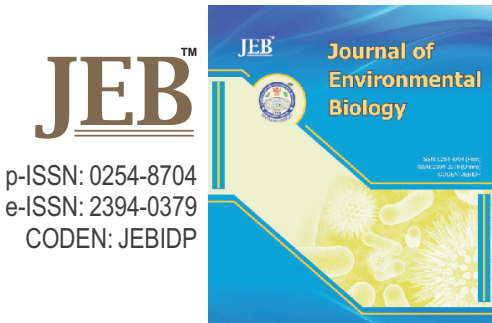

\title{
Stomach contents of Plotosus canius (Hamilton, 1822) in the coastal waters of Port Dickson, Peninsular Malaysia
}

Authors Info

B.I. Usman ${ }^{2}$, S.M.N. Amin ${ }^{1 *}$, A. Arshad', Mohd. S. Kamarudin and M.K. Abu Hena ${ }^{3}$

'Department of Aquaculture, Faculty of Agriculture, Universiti Putra Malaysia, 43400, UPM Serdang, Selangor, Malaysia ${ }^{2}$ Department of Fisheries and Aquaculture, Faculty of Agriculture, Bayero University, 700 241, Kano, Nigeria

${ }^{3}$ Department of Animal Science and Fishery, Faculty of Agriculture and Food Sciences, Universiti Putra Malaysia, Bintulu Sarawak Campus, 97008, Malaysia

${ }^{*}$ Corresponding Author Email : smnabd@gmail.com

Key words Index of preponderance Opportunistic feeder Plotosus canius Stomach contents Stomach fullness

Publication Info Paper received : 20.03.2017 Revised received : 05.07.2017 Re-revised received : 30.09 .2017 Accepted : 28.12.2017

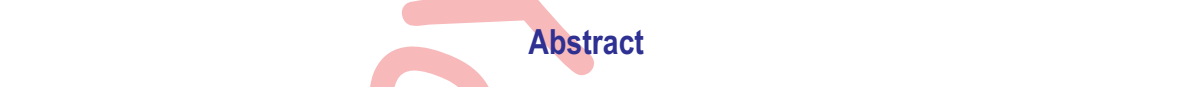

Aim : Grey-eel catfish, Plotosus canius, are euryhaline fish and native throughout South East Asia, but there is limited information regarding their feeding habits.

Methodology : In this study, the stomach contents from 234 samples of $P$. canius were analysed from the coastal waters of Port Dickson, Peninsular Malaysia. Sampling was carried over a period of twelve months (January to December, 2012).

Results : The study revealed that $61.54 \%$ of the stomachs contained food at various degrees of fullness, while the remaining (38.46\%) were empty. According to index of preponderance (IP), the stomach contents in $P$. canius were composed of six major groups viz; fish and fish parts $(38.00 \%)$, crustaceans $(26.69 \%)$, molluscs $(25.58 \%)$, sand and mud (6.68\%), debris and detritus (2.99\%) and unidentified items (0.06).

Interpretation : The diet composition revealed a wide range of prey items of animal origin indicating that the fish is carnivorous. The findings of the present study would be very useful for the development of aquaculture of the fish.
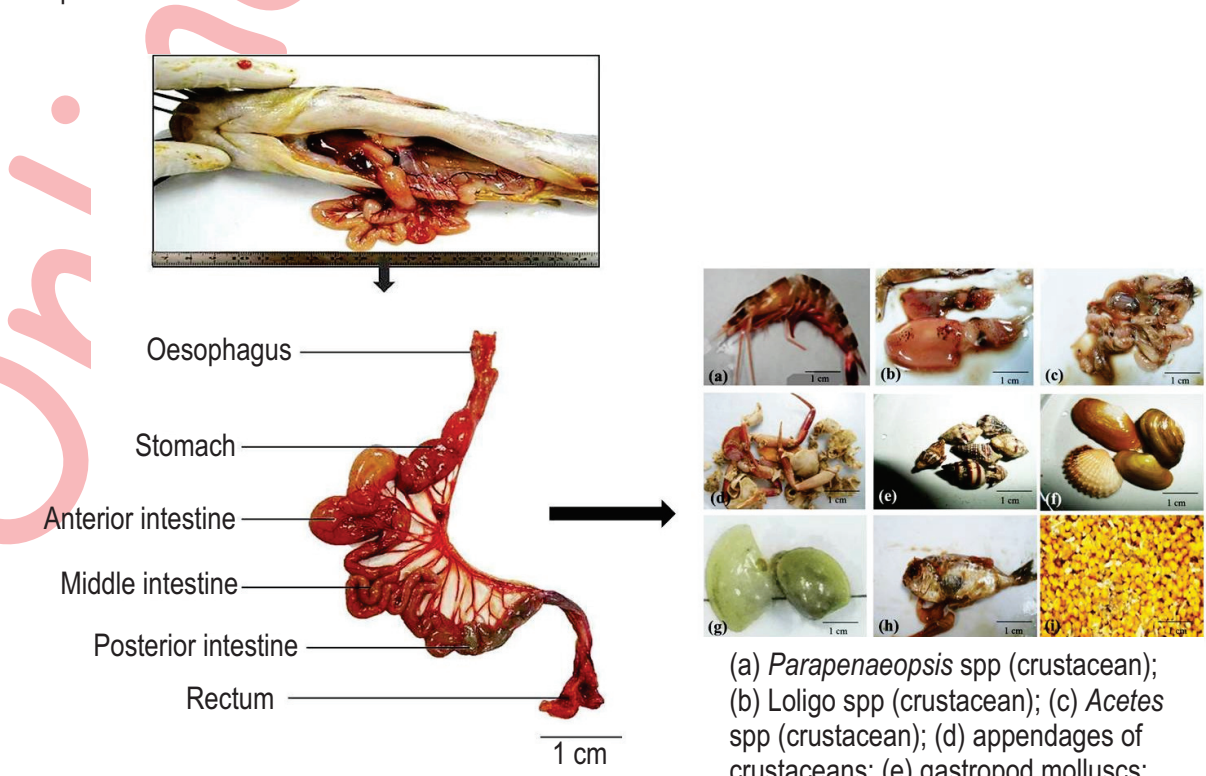

(a) Parapenaeopsis spp (crustacean);

(b) Loligo spp (crustacean); (c) Acetes spp (crustacean); (d) appendages of crustaceans; (e) gastropod molluscs; $(\mathrm{f}, \mathrm{g})$ bivalve mollucs; (h) small fish; (i) fish eggs 


\section{Introduction}

Food is one of the main factors that affects the dynamics of any fish species in the aquatic habitat. Analyzing the stomach contents is relatively easy but also an accurate way to investigate the diet composition and feeding biology (Allison and Sikoki, 2013; Mablouké et al., 2013; Manon and Hossain, 2013). Acquaintance of feeding behavior of a fish is an indispensable tool in the categorizing fish with respect to their diet, mode of feeding and how they feed (Allison and Sikoki, 2013). In addition, information would be very applicable for the protection of species in particular, and the ecosystem at large (Turan et al., 2005; Alhassan and Ansu-Darko, 2011).

Based on the type of food ingested, fishes can be classified as carnivorous, herbivorous, omnivorous or detritivorous. The intestine of fish is modified according to its feeding habit, which is typically shorter and straighter in more carnivorous species. This is because of the short time required by meat to be digested (Pandey and Shukla, 2005; Pathak et al. 2013). Conversely, additional plant materials are eaten by herbivorous fishes and they need extended time for digestion as their intestine is very elongated and extremely folded. In omnivorous fishes, the intermediate condition is found. For some fish cultured under captive conditions, they can increase or decrease their intestinal length, relative to their body, over time based on their diets (Nepal et al., 2018). The grey-eel catfish, Plotosus canius was observed to have a relatively short and slightly folded intestine, indicating this species is carnivorous, but little is known regarding their feeding habits (Sinha, 1984; Ahmed and Haque, 2007; Leh et al., 2012). In this study, the feeding habits and diet composition of $P$. canius in the coastal waters of Port Dickson, Malaysia were examined.

\section{Materials and Methods}

Sample collection : Sampling was conducted between January and December, 2012 in the coastal waters of Port Dickson, Peninsular Malaysia. The stomach contents of $P$. canius were examined monthly. Random samples were used for the monthly stomach content analysis and the food items were examined with the help of naked eye for macro-pieces and under a dissecting microscope for micro-pieces.

Stomach examination : Samples were cleaned and the stomach contents were examined within 2-3 days of storage in $-20^{\circ} \mathrm{C}$. Prior to stomach examination, the stomach was cleaned and excess moisture blotted out using tissue paper. The stomach was then dissected out, and its contents weighed to the nearest $0.01 \mathrm{~g}$ using a digital weighing balance (Model-AY220, Shimadzu Corporation, Japan). The stomach contents were examined both macroscopically and microscopically (Model- EMT 21444, Labax Co, Japan) for taxonomic identification of various food items with the aid of standard reference texts of Lovett (1981); Seng, (1994) and Tan and $\mathrm{Ng}$ (1994). Stomach fullness was assessed using an empirical scale as shown in Table 1.

Stomach content analysis : The analysis of stomach content was done using percentage frequency of occurrence (\% FO) and percentage composition by weight $(\% \mathrm{Cw})$, for each prey item, by the following formulas given bellow:

$\% \mathrm{FO}=\frac{\text { number of stomachs containing a particular prey item }}{\text { number of non-empty stomachs examined }} \times 100$

(Hyslop, 1980)

$\% \mathrm{Cw}=\frac{\text { weight of a particular prey item in all stomachs examined }}{\text { Total weight of all prey items in all stomachs }} \times 100$

(Needham, 1962)

The relative importance of prey item in the diet of $P$. canius was examined by index of preponderance (IP) according to Needham (1962) as follows:

$$
\mathrm{IP}=\frac{(\% \mathrm{Cw} \times \% \mathrm{FO})}{\sum((\% \mathrm{Cw} \times \mathrm{FO})}
$$

\section{Results and Discussion}

The percentages of stomach fullness of $P$. canius in the various months of the study period are given in Table 2. Empty stomach was highest (70\%) in April and lowest (20\%) in July. The maximum proportion $(30.0 \%)$ of full stomachs was found in July, and the lowest $(05.0 \%)$ was observed in October. For $3 / 4$ full stomachs, the highest percentage $(25.0 \%)$ was in the month of January and lowest $(05.0 \%)$ in October and November. Highest percentage of $1 / 2$ full stomachs $(35.0 \%$ ) was also in January, while the lowest (05.0\%) was found in April. The highest percentage (40.0\%) of $1 / 4$ full stomachs was recorded in October, whereas the lowest $(10.0 \%)$ were observed during the months of June and August. Throughout the period of study, the average percentage of stomach fullness was $10.26 \%$ for full stomachs, $11.54 \%$ for $3 / 4$ full stomachs, $18.38 \%$ for $1 / 2$ full stomachs, $21.36 \%$ for $1 / 4$ full stomachs and $38.46 \%$ for empty stomachs. Sinha (1984) studied the food preference of $P$. canius from Hooghly-Matlah estuary, India and found that February to July was the period of less intense feeding, based on no observations of full stomachs.

Table 1 : Empirical scale of $P$. canius stomach fullness divided into five classes, as outlined in this study

\begin{tabular}{ll}
\hline $\begin{array}{l}\text { Fullness } \\
\text { classification }\end{array}$ & Description \\
\hline Full stomach & $\begin{array}{l}\text { Stomach massively stuffed with enormous amount } \\
\text { of small prey or a few large preys. }\end{array}$ \\
$3 / 4$ full stomach & $\begin{array}{l}\text { Stomach adequately stuffed with substantial } \\
\text { amount of small preys or a few large preys. }\end{array}$ \\
$1 / 2$ full stomach & $\begin{array}{l}\text { Stomach moderately stuffed with adequate amount } \\
\text { of prey. }\end{array}$ \\
$1 / 4$ full stomach & $\begin{array}{l}\text { Stomach slightly stuffed with a few or substantial } \\
\text { small preys. }\end{array}$ \\
Empty stomach & $\begin{array}{l}\text { Stomach scarcely stuffed with no or/and } \\
\text { few small preys. }\end{array}$ \\
\hline
\end{tabular}


Table 2 : Percentage of stomach fullness of $P$. canius in the coastal waters of Port Dickson during January to December, 2012

\begin{tabular}{|c|c|c|c|c|c|c|}
\hline Months & $\begin{array}{l}\text { No. of fish } \\
\text { examined }\end{array}$ & $\begin{array}{l}\text { Full } \\
(1)\end{array}$ & $\begin{array}{l}3 / 4 \\
\text { Full }\end{array}$ & $\begin{array}{l}1 / 2 \\
\text { Full }\end{array}$ & $\begin{array}{l}1 / 4 \\
\text { Full }\end{array}$ & $\begin{array}{l}\text { Empty } \\
(0)\end{array}$ \\
\hline Jan & 20 & -- & 25.00 & 35.00 & 15.00 & 25.00 \\
\hline Feb & 19 & -- & 10.53 & 21.05 & 26.32 & 42.11 \\
\hline Mar & 20 & -- & -- & 25.00 & 25.00 & 50.00 \\
\hline Apr & 20 & -- & -- & 05.00 & 25.00 & 70.00 \\
\hline May & 15 & 06.67 & 13.33 & 13.33 & 26.67 & 40.00 \\
\hline Jun & 20 & 15.00 & 15.00 & 25.00 & 20.00 & 25.00 \\
\hline Jul & 20 & 30.00 & 20.00 & 20.00 & 10.00 & 20.00 \\
\hline Aug & 20 & 15.00 & 20.00 & 20.00 & 10.00 & 35.00 \\
\hline Sep & 20 & 15.00 & 10.00 & 15.00 & 20.00 & 40.00 \\
\hline Oct & 20 & 05.00 & 05.00 & 20.00 & 40.00 & 30.00 \\
\hline Nov & 20 & 20.00 & 05.00 & 10.00 & 20.00 & 45.00 \\
\hline Dec & 20 & 15.00 & 15.00 & 10.00 & 20.00 & 40.00 \\
\hline$\%$ Occurrence & 234 & 10.26 & 11.54 & 18.38 & 21.36 & 38.46 \\
\hline
\end{tabular}

However in this study, the results showed that the period of less intense feeding of $P$. canius in the coastal waters of Port Dickson, Malaysia, was from January to April. These findings also revealed that $38.46 \%$ of specimens had empty stomachs and the remaining $61.54 \%$ stomachs contained food, which were full, $3 / 4$ full, $1 / 2$ full and $1 / 4$ full. The maximum percentages of full and empty stomach of $P$. canius were found in July and April, respectively. This could be associated to pressures due to spawning activity, as well as seasonal abundance of the prey items. Other probable reasons could be due to passive sampling gear, intermittent feeding habit, high rate of digestion (Allison and Sikoki, 2013) and/or regurgitation of stomach contents after capture (Mablouké et al., 2013).

Predatory fishes have also been reported to have irregular feeding habits and show preference for larger items when available (Oribhabor and Ogbeibu, 2012). There appeared

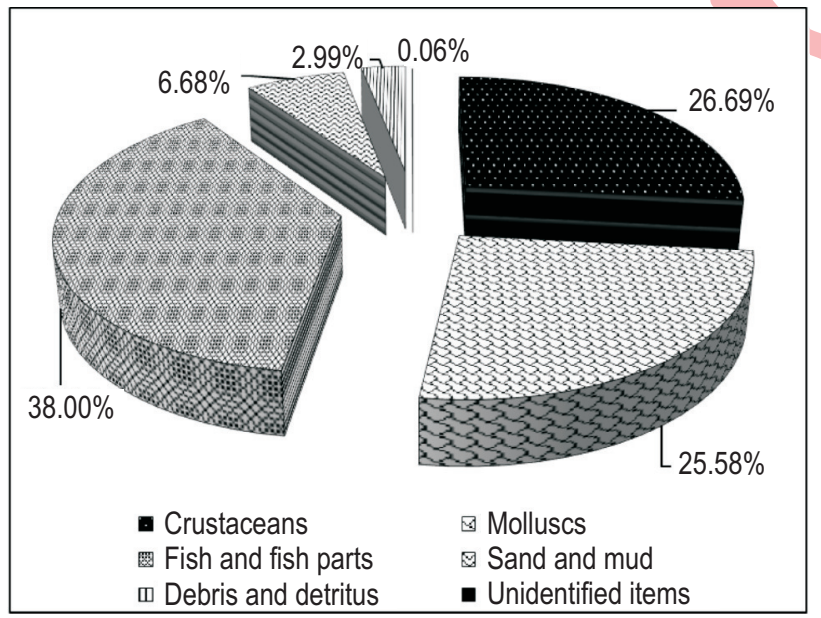

Fig. 1 : Index of preponderance (\% I.P.) of the prey items of $P$. canius during January to December, 2012 to be a sharp rise in feeding intensity during July onwards, and might be ascribed to post spawning activity and large number of spent fishes that began to actively feed again. High numbers of empty stomachs were observed during March and April and suggests a period of poor feeding activity, which also corresponded to the occurrence of more number mature fishes about to spawn. This implied a shift in the feeding habits of $P$. canius. Poor feeding during periods of peak spawning activity have also been described in Nemipterus japonicas (Rao and Rao, 1991), Mastacembelus armatus (Serajuddin and Mustafa, 1994), Amblypharyngodon mola (Mamun et al., 2004), Mysteus nemurus (Khan et al., 2011) and Macrognathus pancalus (Serajuddin and Ali, 2011).

Analyses of different prey items revealed 26 important items (Table 3, \% IP>0.05), belonging to six major groups; crustaceans, molluscs, fish and fish parts, sand and mud, debris

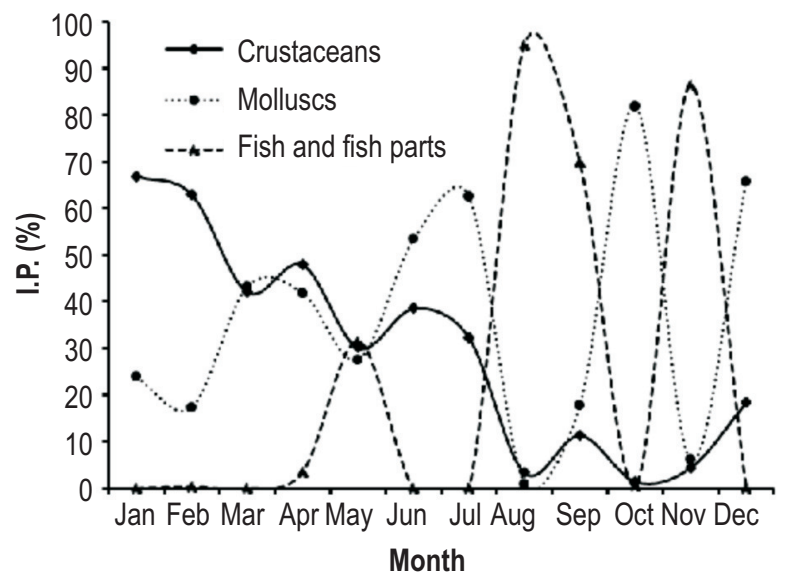

Fig. 2 : Monthly variation of Index of preponderance (\% I.P.) of three major prey items in the stomach of $P$. canius in the coastal waters of Port Dickson during January to December, 2012 
Table 3 : Overall diet composition of $P$. canius ranked by index of preponderance (\% I.P.) in the coastal waters of Port Dickson during January to December, 2012

\begin{tabular}{|c|c|c|c|c|c|}
\hline Food items & Frequency (f) & Weight $(\mathrm{g})$ & $\% \mathrm{FO}$ & $\% \mathrm{Cw}$ & \% I.P. \\
\hline Crustaceans & 103 & 108.33 & 25.07 & 23.86 & 26.69 \\
\hline Portunus spp. & 10 & 20.42 & 2.43 & 4.50 & 1.59 \\
\hline Neopisserma spp. & 8 & 8.03 & 1.95 & 1.77 & 0.50 \\
\hline Sesarma spp. & 3 & 2.84 & 0.73 & 0.62 & 0.07 \\
\hline Fenneropeneus spp. & 1 & 3.18 & 0.24 & 0.70 & 0.02 \\
\hline Acetes spp. & 11 & 4.48 & 2.68 & 0.99 & 0.39 \\
\hline Parapenaeopsis spp. & 1 & 5.68 & 0.24 & 1.25 & 0.04 \\
\hline Thalamite spp. & 1 & 0.73 & 0.24 & 0.16 & 0.006 \\
\hline Charabdis spp. & 7 & 7.62 & 1.70 & 1.68 & 0.42 \\
\hline Metapenaeus spp. & 1 & 1.82 & 0.24 & 0.40 & 0.01 \\
\hline Rhinolambrus spp. & 1 & 2.26 & 0.24 & 0.50 & 0.02 \\
\hline Appendages of crustaceans & 59 & 51.27 & 14.36 & 11.29 & 23.62 \\
\hline Molluscs & 142 & 148.04 & 34.55 & 32.61 & 25.58 \\
\hline Modiolus spp. & 6 & 14.78 & 1.46 & 3.26 & 0.69 \\
\hline Sinovacula spp. & 3 & 2.10 & 0.73 & 0.46 & 0.05 \\
\hline Anadara spp. & 12 & 17.46 & 2.92 & 3.85 & 1.64 \\
\hline Obicularia spp. & 3 & 4.27 & 0.73 & 0.94 & 0.10 \\
\hline Pholas spp. & 16 & 14.97 & 3.89 & 3.30 & 1.87 \\
\hline Danax spp. & 1 & 0.38 & 0.24 & 0.08 & 0.003 \\
\hline Marcia spp. & 1 & 0.97 & 0.24 & 0.21 & 0.008 \\
\hline Strombus spp. & 5 & 3.36 & 1.22 & 0.74 & 0.13 \\
\hline Phaxas spp. & 7 & 8.76 & 1.70 & 1.93 & 0.48 \\
\hline Siput spp. & 1 & 0.60 & 0.24 & 0.13 & 0.005 \\
\hline Perna spp. & 1 & 3.05 & 0.24 & 0.67 & 0.02 \\
\hline Loligo spp. & 4 & 8.14 & 0.97 & 1.79 & 0.25 \\
\hline Geloina spp. & 1 & 1.59 & 0.24 & 0.35 & 0.01 \\
\hline Barbatia spp. & 6 & 6.69 & 1.46 & 1.47 & 0.31 \\
\hline Cryptomia spp. & 3 & 3.13 & 0.73 & 0.69 & 0.07 \\
\hline Glauconome spp. & 4 & 7.37 & 0.97 & 1.62 & 0.23 \\
\hline Cerithidea spp. & 3 & 4.28 & 0.73 & 0.94 & 0.10 \\
\hline Terebralia spp. & 3 & 3.31 & 0.73 & 0.73 & 0.08 \\
\hline Trochus spp. & 1 & 1.88 & 0.24 & 0.41 & 0.01 \\
\hline Shell fragments of molluscs & 61 & 40.95 & 14.84 & 9.02 & 19.51 \\
\hline Fish and fish parts & 38 & 176.00 & 9.25 & 38.77 & 38.00 \\
\hline Small fish & 2 & 9.43 & 0.49 & 2.08 & 0.15 \\
\hline Fish eggs & 31 & 154.88 & 7.54 & 34.12 & 37.49 \\
\hline Other fish parts & 5 & 11.69 & 1.21 & 2.57 & 0.36 \\
\hline Sand and mud & 64 & 13.37 & 15.56 & 2.95 & 6.68 \\
\hline Debris and detritus & 60 & 6.37 & 14.60 & 1.40 & 2.99 \\
\hline Unidentified items & 4 & 1.86 & 0.97 & 0.41 & 0.06 \\
\hline
\end{tabular}

Table 4 : Index of preponderance (\% I.P.) of prey items in the stomachs of $P$. canius in the coastal waters of Port Dickson during January to December, 2012

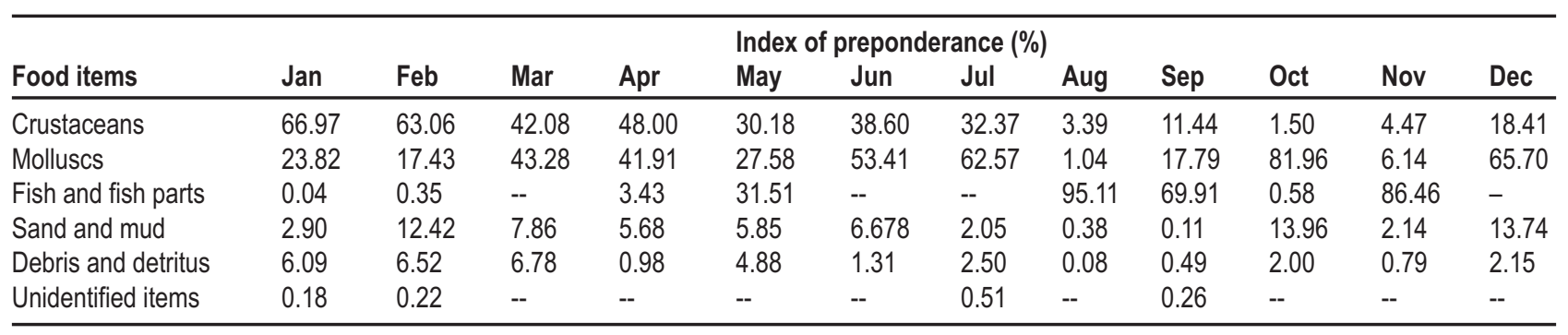


and detritus and unidentified items. The most important prey items (Fig. 1) in the stomachs, according to index of preponderance $(\% \mathrm{IP})$, were fish $(38.0 \%)$ followed by crustaceans $(26.69 \%)$, molluscs $(25.58 \%)$, sand and mud $(6.68 \%)$, debris and detritus $(2.99 \%)$ and unidentified items $(0.06 \%)$. This finding is similar to the findings of Leh et al. (2012); Ahmed and Haque (2007) and Sinha (1984), with some minor variations. Leh et al. (2012) reported crustaceans, molluscs and fish as the main food items in the stomachs of $P$. canius in the mangrove estuary of Malaysia. They further stated that crustaceans formed $70 \%$ volume of the food items. It was reported by Sinha (1984) that the main diet composition of the major food items of the fish were crustaceans, fish and molluscs as well as aquatic insects. Aquatic insects were likely found because $P$. canius were sampled in various waterways, including freshwater systems, whereas in this study the fishes were only sampled from coastal marine waters.

Monthly changes in index of preponderance (\%IP) of stomach contents of P. canius is given in Table 4. Index of preponderance $(\% \mathrm{IP})$ of three most dominant groups of food items in the stomachs of $P$. canius revealed that fish formed the highest part of fish diet composition (Fig. 1). The highest \%IP was recorded in August (95.11\%), followed by November $(86.46 \%)$, and the lowest was $0.04 \%$ in January. Dietary components of fish were not found during March, June, July and December (Fig. 2). Crustaceans constituted the second most important item in the diets of $P$. canius (Fig. 2) and were observed in almost every month of the stomach samples. The highest \% IP for crustaceans was observed in January (66.97\%), followed by February $(63.06 \%)$, and the lowest was recorded in October $(1.50 \%)$. In general, the consumption of crustaceans was low during AugustDecember. Molluscs were the third most important stomach content in $P$. canius from the coastal waters of Port Dickson and comprised of both gastropods and bivalve molluscs throughout the year. The \%IP of molluscs were, especially higher, during July $(62.57 \%)$, October $(81.96 \%)$ and December $(65.70 \%)$ and mollusc intake was, especially low, during January - February, May, August and November (Fig. 2). Although there were monthly fluctuations in the quantity of prey items consumed, little variation was found in the quality of prey items consumed (Table 4). This suggests that $P$. canius is an opportunistic feeder. However, the observed monthly variations in the composition of the food could be due to seasonal fluctuations and occurrence of each diet component. Similar observation was reported by Leh et al. (2012) and Oribhabor and Ogbeibu (2012).

Sand and mud were observed in the stomachs of $P$. canius throghout all the months of the study period, but these were in small amounts and the $\%$ IP fluctuated from $0.11 \%$ in August to $13.74 \%$ in December (Table 4). Debris and detritus was also detected in all the months of the study period, which varied between $0.08 \%$ in August and $6.78 \%$ in March. The minute quantities of sand, mud and debris were likely consumed incidentally when hunting benthic prey. Allison and Sikoki (2013) also considered sand and mud as non-food items because they typically appear in the guts of samples that were caught at the bottom (bottom feeders). Sand and mud have been shown to be continuously existing in the diet composition of the bottom feeders (Oribhabor and Ogbeibu, 2012).

This study showed the feed preferences of $P$. canius over one year and provides a better understanding regarding their ecological roles in the coastal waters of Malaysia. This may also assist with their management and preservation.

\section{Acknowledgments}

This work is funded by Universiti Putra Malaysia (UPM) under Research University Grant Scheme (RUGS) with a Grant no. 05-02-12-1703RU, vote no. 9327300. Extended thanks to Mohd. Hazmadi Bn Zakariya for helping during field sampling.

\section{References}

Alhassan, E. H. and M. Ansu-Darko: Food and feeding habits of a potential aquaculture candidate, the black Nile catfish, Bagrus bajad in the Golinga reservoir. Australian J. Basic Appl. Sci., 5, 354-359 (2011).

Allison, M. E. and F. D. Sikoki: Food and feeding habits of Parailia pellucida (Boulenger, 1901) (Schilbeidae) in the freshwater reaches of the nun river of the Niger Delta, Nigeria. Int. J. Adv. Fish. Aquat. Sci., 1, 1-14 (2013).

Arendt, M. D., J. E. Olney and J. A. Lucy: Stomach content analysis of cobia, Rachycentron canadum, from lower Chesapeake Bay. Fishery bulletin-national oceanic and atmospheric administration, 99, 665-670 (2001).

Azadi, M. A., M. Nasiruddin and A. Rahman: Food and feeding habits of the clupeid, Gonialosa manmina (Ham.) from the Kaptai Lake, Bangladesh. The Chittagong Univ. J. B. Sci., 4, 53-61 (2013).

Azadi, M. A. and M. Ullah: Food and feeding habits of the ribbon fish, Lepturacanthus savala (Cuvier, 1829) from the Bay of Bangladesh. J.Asiat. Soc. Bangladesh, 35, 57-64 (2009).

Hyslop, E. J.: Stomach contents analysis-A review of methods and their application. J. Fish Biol., 17, 411-429 (1980).

Joyce, W. N., S. E. Campana, L. J. Natanson, N. E. Kohler, H. L. Pratt and C. F. Jensen: Analysis of stomach contents of the porbeagle shark (Lamna nasus Bonnaterre) in the northwest Atlantic. ICES J. Mar. Sci.: Journal du Conseil, 59, 1263-1269 (2002).

Kanwal, B. P. S. and S. S. Pathani: Food and feeding habits of a hill stream fish, Garra lamta (Hamilton-Buchanan) in some tributaries of Suyal River, Kumaun Himalaya, Uttarakhand (India). Int. J. Food Nutr. Sci., 1, 16-22 (2012).

Khan, M. S., M. A. Ambak and A. K. M. Mohsin: Food and feeding biology of a tropical freshwater catfish, Mystus nemurus Cuvier and Valenciennes with reference to its functional morphology. Ind. J. Fish., 35, 78-84 (2011).

Leh, M. U. C., A. Sasekumar and L. L. Chew: Feeding biology of eel catfish Plotosus canius Hamilton in a Malaysian mangrove estuary and mudflat. Raffles Bull. Zool., 60, 551-557 (2012).

Lovett, D. L.: A guide to the shrimps, prawns, lobsters, and crabs of Malaysia and Singapore: Faculty of Fisheries and Marine Science, 
Universiti Pertanian Malaysia (1981).

Mablouké, C., J. Kolasinski, M. Potier, A. Cuvillier, G. Potin, L. Bigot and S. Jaquemet: Feeding habits and food partitioning between three commercial fish associated with artificial reefs in a tropical coastal environment. Afr. J. Marine Sci., 35, 323-334 (2013).

Mamun, A., K. M. A. Tareq and M. A. Azadi: Food and feeding habits of Amblypharyngodon mola (Hamilton) from Kaptai Reservoir, Bangladesh. Pak. J. Biol. Sci., 7, 584-588 (2004).

Manon, M. R. and M. D. Hossain: Food and feeding habit of Cyprinus carpio var. specularis. J. Sci. Found., 9, 163-169 (2013).

Needham, P. R.: A guide to the study of fresh-water biology. Holden-Day. Inc. San Francisco, California (1962).

Nepal, S., V. Kumar, H.P.S. Makkar, T. Stadtlander, N. Romano and K. Becker: Comparative nutritional value of Jatropha curcas protein isolate and soy protein isolate in common carp. Fish Physiol. Biochem., 44, 143-162 (2018).

Oribhabor, B. J. and A. E. Ogbeibu: The food and feeding habits of fish species assemblage in a Niger Delta mangrove creek, Nigeria. J. Fish. Aquat. Sci., 7, 134-149 (2012).

Pandey, K. and J. P. A. Shukla: A Textbook of Fish and Fisheries. Rastogi Publications (2005).

Pathak, B. C., M. Zahid and M. Serajuddin: Length-weight, length-length relationship of the spiny eel, Macrognathus pancalus (Hamilton 1822) sampled from Ganges and Brahmaputra river basins, India. Iran. J. Fish. Sci., 12, 170-182 (2013).
Rao, D. M. and K. S Rao: Food and feeding behaviour of Nemipterus japonicus (Bloch) populations off Visakhapatnam, South India. J. Mar. Biol. Ass. India. Cochin, 33, 335-345(1991).

Seng, Y. T: Molluscs in Malaysia. $2^{\text {nd }}$ Edn., Kuala Lumpur Malaysia: Department of Fisheries, Ministry of Agriculture Malaysia (1994).

Serajuddin, M. and R. Ali: Food and feeding habits of striped spiny eel, Macrognathus pancalus (Hamilton). Indian J. Fish., 52, 81-86 (2011).

Serajuddin, M. and S. Mustafa: Feeding specialization in adult spiny eel, Mastacembelus armatus. Asian Fish. Sci., 7, 63-65 (1994).

Sinha, M.: Food preference studies of Plotosus canius Hamilton and its cultural suitability. Proceedings: Anim. Sci., 93, 437-443 (1984).

Srivastava, S. M., S. P. Singh and A. K. Pandey: Food and feeding habits of threatened Notopterus notopterus in Gomti river, Lucknow (India). J. Exp. Zool., India, 15, 395-402 (2012).

Tan, C. G. S. and P. K. L. Ng: An annotated checklist of mangrove brachyuran crabs from Malaysia and Singapore. Hydrobiologia, 285, 75-84 (1994).

Turan, C., S. Yalcin, F. Turan, E. Okur and I. Akyurt: Morphometric comparisons of African catfish, Clarias gariepinus, populations in Turkey. Folia Zool., 54, 165-172 (2005).

Urban, D.: Food habits of Pacific cod and walleye pollock in the Northern Gulf ofAlaska. Mar. Ecol. Prog. Seri., 469, 215-222 (2012). 